\title{
Internal Financial Controls Practices of District Mosques in Central Region of Malaysia
}

\author{
Mohamad Noorman Masrek, Intan Salwani Mohamed, Norzaidi Mohd Daud, Roshayani Arshad, and \\ Normah Omar
}

\begin{abstract}
Controls over the financial activities of the Non-profit organizations (NPOs) are very important due to the fact that NPOs are managing public funds received from government, corporate and public donations. The objective of this study is to investigate the basic internal financial controls practices among Mosques in the state of Selangor and Wilayah Persekutuan Kuala Lumpur (central region of Malaysia). In Malaysia which consists of 14 states, Mosque is an example of NPOs which falls under religious category and monitored by Islamic bodies of each state. A state is divided into several $\mathrm{s}$. Mosque refers to the main mosque in an area which received funding from government, corporate and public donations. Central region of Malaysia was chosen as the population of interest due to the fact that this region is the most developed area which received lots of funding. Unstructured interviews and review of documents were conducted to investigate the current practices of basic financial controls on receipt of income and on disbursing funds. The findings suggested that internal controls practices by Mosques on both receipt of income and funds disbursement requires significant attention regarding the segregation of duties element. Other elements of internal controls such as physical custody, recording of transactions, and authorization are at the accepted level.
\end{abstract}

Index Terms - Internal controls, district mosque, Malaysia.

\section{INTRODUCTION}

Non Profit Organizations (NPOs) is becoming recognized as playing important role in communities (Sinclair, 2010). However, various types of fraud, mismanagement or error perpetrated on NPOs have become more and more ingenious, and therefore implementing good internal control system (ICS) could help an organization to ensure the reliability of its financial reporting system, to safeguard its assets, to make sure that financial statements are prepared timely and most importantly, to prevent fraud and error from happening [2]. Poor internal control practices not only creates an opportunity for abuse, fraud, and corruption, but also can send message to employees, stakeholders, and other individuals outside the organizations indicating management ignorance about protecting the entity's assets.

Manuscript received July 2, 2013; revised January 8, 2014. This work was funded by Accounting Research Institute under Ministry of Higher Education Malaysia.

Mohamad Noorman Masrek and Normah Omar are with Accounting Research Institute / Faculty of Information Management, UiTM Malaysia (e-mail: mnoorman@salam.uitm.edu.my,normah645@salam.uitm.edu.my).

Intan Salwani Mohamed and Roshayani Arshad are with Accounting Research Institute / Faculty of Accountancy, UiTM Malaysia (e-mail: intan838@salam.uitm.edu.my, roshayani@salam.uitm.edu.my).

Norzaidi Mohd Daud is with Accounting Research Institute / Arshad Ayub Graduate Business School, UiTM Malaysia (e-mail: zaidiuitm2000@yahoo.com).
Although studies focusing on internal control practices among non-profit organization have been quite extensively reported in the literature, in the context of Malaysia, studies on internal control practices among mosques are still very limited whereas; Muslims in Malaysia represent $60.4 \%$ of the total population of $29,179,952$ people (as in the year 2012). Against this background, the main objective of the study attempts to investigate internal control practices among District Mosques, a religious organization for Muslims in central region of Malaysia. More specifically, the study focuses on (i) internal control practices on receipt of income which covers physical custody, segregation of duties, and recording of transactions, and (ii) internal control practices on disbursing funds which covers authorization, segregation of duties, and physical custody.

\section{LITERATURE REVIEW}

\section{A. Overview of Mosque Administration}

Malaysia comprises of fourteen states and the administration of Islamic affairs are done by two organizations; the Islamic Religious Council (IRC) (responsible for policymaking), and the Islamic Religious Department (IRD) (responsible for carrying out the policies and procedures for developing and advancing Islam in each state). Besides, the Department of Islamic Development (JAKIM) coordinates the standardization of each state's method of administering its Islamic affairs at the federal level [3].

In the state of Selangor, the IRC is known as "Majlis Agama Islam Selangor" (MAIS) and the IRD is represented by "Jabatan Agama Islam Selangor" (JAIS). In Wilayah Persekutuan Kuala Lumpur, the IRC is identified as "Majlis Agama Islam Wilayah Persekutuan" (MAIWP), and the IRD is known as "Jabatan Agama Islam Wilayah Persekutuan" (JAWI). Mosques management in Selangor falls under JAIS, and JAWI is responsible for Mosques management in Wilayah Persekutuan Kuala Lumpur. There are four categories of Mosques; State Mosque, Royal Mosque, District Mosque, and Kariah Mosque. A state is divided into several areas. District Mosque refers to the main mosque in an area which received funding from government, corporate and public donations.

The Mosque is one of the most critical and significant institutions for Muslims [9]. It is not only a place where Muslims perform their daily prayers, but also plays the role as a centre of many other activities, either directly related to worship or non-worship activities [9]. Shouldering various roles and activities, the mosque cannot avoid the need of fund 
and cash flow to guarantee all those activities can be managed well [9]. As Mosques are dealing with public funds received from government, corporate and public donations, controls over the financial activities in handling funds received and expended by the organization has become an interesting area to be investigated.

\section{B. Internal Control}

Internal controls are systems of policies and procedures that protect the assets of an organization, create reliable financial reporting, promote compliance with laws and regulations and achieve effective and efficient operations [4]. Not only related to accounting and reporting, these system also relate to the organization's communication processes, internally and externally, and include procedures for i) handling funds received and expended by the organization, ii) preparing appropriate and timely financial reporting to board members and officers, iii) conducting the annual audit of the organization's financial statements, iv) evaluating staff and programs, v) maintaining inventory records of real and personal property and their whereabouts and vi) implementing personnel and conflicts of interest policies.

The effective implementation and monitoring of internal control system will ensure that NPOs such as religious organizations meet their objectives, such as providing services to the community professionally, while utilising resources efficiently and minimising the risk of fraud, mismanagement or error [5]. Internal control principles suggest that internal control system (ICS) is the primary accountability and governance tool an organization can establish and use to provide accountability to its stakeholders as well as to help deter, prevent, and detect fraud and corruption [6], [7].

\section{Internal Controls on Receipt of Income and Disbursement Funds}

As the procedures of handling funds received and expended by the organization is an important component to achieve sound internal controls, it is therefore important to evaluate the internal control practices on receipt of income and disbursement of funds due to the fact that religious organizations appear to have lack of expertise and commitment in practicing proper internal controls. Prior studies have suggested that the lack of regulations and a proper code of conduct as regards accounting and financial management practices in churches (and other religious organizations) have contributed to their inefficiency [8]. Duncan and Flesher [10] also claimed that fraud and embezzlement are becoming more common in western church institutions. Controls related to physical custody of cash and cheques, segregation of duties, recording of transactions, and authorization of payments are the suggested control elements on receipt of income and disbursing funds [3].

\section{MethodOLOGY}

The study adopted the qualitative research approach with unstructured interview as the main data collection technique involving 13 District Mosques in the central region of Malaysia as suggested by JAWI and JAIS. The questions asked for the unstructured interview was adapted from the audit working papers on internal control systems for receipt of income (Table I) and disbursing funds (Table II) and detail answers for certain questions were sought when necessary based on the interviewer's judgment. The checklist regarding internal controls on receipt of income were classified into three; physical custody of cash and cheques collection, segregation of duties among persons who counted money from collection boxes and the person who made entries in the cashbook, and recording and verification of transactions for cash/cheques received. For internal controls checklist on disbursing funds, authorization of payments, segregation of duties in terms of preparing payment documents and physical custody of cheque books were asked during the interview session. Besides unstructured interview, review of documents was also done to gain more insights regarding the internal controls practices by District Mosques. Descriptive analysis was conducted to analyze the data.

TABLE I: INTERNAL CONTROL ON RECEIPT OF INCOME

\begin{tabular}{|c|c|}
\hline \multicolumn{2}{|c|}{ SECTION A: INTERNAL CONTROLS ON RECEIPT OF INCOME } \\
\hline $\begin{array}{l}\text { Physical } \\
\text { Custody } \\
\text { (PC) }\end{array}$ & Physical Custody (PC) \\
\hline PC1 & All collection boxes are sealed or locked \\
\hline $\mathrm{PC} 2$ & All collection boxes opened regularly \\
\hline PC3 & $\begin{array}{l}\text { Number of people present during the opening of the } \\
\text { collection boxes (i) One person; (ii) Two persons; (iii) More } \\
\text { than two persons }\end{array}$ \\
\hline PC4 & $\begin{array}{l}\text { Counting of money from collection boxes done promptly } \\
\text { once opened (i) Yes; (ii) Only few (iii) Not at all }\end{array}$ \\
\hline PC5 & $\begin{array}{l}\text { All money received from public donations are deposited at } \\
\text { least on the next working day (i) Yes (ii) Only few (iii) Not at } \\
\text { all }\end{array}$ \\
\hline PC6 & $\begin{array}{l}\text { Incoming monies are not used to pay any expenses before } \\
\text { banking in first }\end{array}$ \\
\hline PC7 & $\begin{array}{l}\text { All cash received are placed in a safe place (e.g.: locked } \\
\text { box/drawer) if it cannot be banked on the same day }\end{array}$ \\
\hline PC8 & $\begin{array}{l}\text { All cheques received are placed in a safe place (e.g.: locked } \\
\text { box/drawer) if it cannot be banked on the same day }\end{array}$ \\
\hline PC9 & $\begin{array}{l}\text { Access to the safe/locked box is limited to authorized } \\
\text { person(s) only }\end{array}$ \\
\hline \multicolumn{2}{|c|}{ Segregation of Duties (SD) } \\
\hline SD1 & $\begin{array}{l}\text { The counting of money from collection boxes is done by a } \\
\text { different person from the person who makes entries in the cash } \\
\text { book }\end{array}$ \\
\hline \multicolumn{2}{|c|}{ Recording of Transactions (RT) } \\
\hline RT1 & The mosque maintain a cashbook for cash/cheques received \\
\hline RT2 & $\begin{array}{l}\text { Checks are conducted to ensure the incoming receipts are } \\
\text { recorded regularly }\end{array}$ \\
\hline RT3 & $\begin{array}{l}\text { Cash/cheques recorded in the cashbook are verified with the } \\
\text { bank pay-in slips }\end{array}$ \\
\hline RT4 & $\begin{array}{l}\text { The pay-in slips or cash receipts recorded in the cashbook are } \\
\text { verified with the relevant bank statements }\end{array}$ \\
\hline
\end{tabular}

\section{FINDINGS}

\section{A. Receipts of Income: Physical Custody}

Under physical custody, questions were divided into three: collection (PC1, PC2, PC3, and PC4); banking -in (PC5, and PC6); and safekeeping (PC7, PC8, and PC9). In terms of physical custody of collection boxes, the objective of controls is to ensure all cash collections boxes is safeguarded, and once opened, the cash should be promptly counted, recorded and deposited to the bank. 
TABLE II: INTERNAL CONTROL ON DISBURSEMENT FUND SECTION B: INTERNAL CONTROLS ON DISBURSEMENT FUND

\begin{tabular}{|c|c|}
\hline \multicolumn{2}{|c|}{ Authorization (A) } \\
\hline No & Controls \\
\hline A1 & Payments are supported by invoice \\
\hline A2 & $\begin{array}{l}\text { Payment vouchers are prepared when making } \\
\text { payments }\end{array}$ \\
\hline A3 & $\begin{array}{l}\text { There are limits imposed on payment approvals at } \\
\text { various levels of the committee members of the } \\
\text { mosque }\end{array}$ \\
\hline \multicolumn{2}{|c|}{ Segregation of Duties (SD) } \\
\hline SD1 & $\begin{array}{l}\text { The person preparing payment vouchers is different } \\
\text { from the person preparing cheques }\end{array}$ \\
\hline SD2 & $\begin{array}{l}\text { The person preparing payment documentation is } \\
\text { different from the person signing cheques }\end{array}$ \\
\hline SD3 & $\begin{array}{l}\text { The person approving payments is different from the } \\
\text { person preparing cheques }\end{array}$ \\
\hline \multicolumn{2}{|c|}{ Physical Custody (PC) } \\
\hline PC1 & $\begin{array}{l}\text { Cheque books are kept in a safe place (e.g.: safe, } \\
\text { locked box or locked drawer }\end{array}$ \\
\hline
\end{tabular}

All District Mosques practiced good physical custody for safeguarding the collection boxes by having sealed or locked boxes, and all collection boxes are opened regularly. These could prevent possibility of theft of the cash collection. Regarding the number of people present during the opening of the collection boxes, there should be at least two people present in order to minimize the chance of theft or fraud. However, only $84.61 \%$ of District Mosques have at least two people present during the opening of collection boxes. As cash is in the most vulnerable form, counting of money from collection boxes should be done promptly once opened to prevent theft and fraud. It was found that $84.62 \%$ of respondents counted the cash collection immediately once the collection box opened.

In terms of banking-in money collected from the collection boxes, $92.31 \%$ of respondents have good controls by depositing at least on the next working day and not using the money to pay any expenses before banking in first. With regard to safekeeping of cash and cheques, it was found that all District Mosques practiced good internal controls by placing cash/cheques in a safe place (e.g.: locked box/drawer) if it cannot be banked on the same day, and access to the safe/locked box is limited to authorized personnel only.

\section{B. Receipt of Income: Segregation of Duties}

With regards to segregation of accounting duties, the main principle is to segregate the three functions; authorization, recording, and custodial functions. Checks and balances are essentials to make embezzlement difficult. For that reasons, no single person should be responsible to perform more than one function [1]. In the case of District Mosques in the central region of Malaysia, segregation of duties regarding the counting of money from collection and the recording of entries in the cash book seemed to be low. Only five District Mosques (38.46\%) segregated these duties.

\section{Receipt of Income: Recording of Transactions}

Financial transactions need to be recorded as it provides audit trail. To ensure the accuracy of the recorded transactions, verification need to be done by authorized personnel [3]. In the current study, 12 District Mosques $(92.31 \%)$ were found to have a good record-keeping of cashbook for cash/cheques received. Since all District Mosques performed regular checking to ensure all incoming receipts are recorded regularly, it was found that one District Mosques did not use cashbook to record cash/cheques received due to lack of accounting knowledge but applying their own recording format. This could be a reason why the score for question RT3 (Cash/cheques recorded in the cashbook are verified with the bank pay-in slips), and RT4 (The pay-in slips or cash receipts recorded in the cashbook are verified with the relevant bank statements) are similar (only 12 District Mosques) due to the reason that one District Mosque did not have cashbook for the purpose of verification.

\section{Receipts of Income: Physical Custody: Average Score of Internal Controls Implementation}

Comparing the three average scores (PC, SD, and RT) on internal controls for receipt of income; it can be concluded that JAWI and JAIS are responsible for carrying out the policies and procedures for developing and advancing Islam in each state should put extra effort regarding the practice of segregation of duties related to collection boxes. As SD was found to have the lowest score of controls implemented $(38.46 \%)$, and due to the fact that cash is vulnerable to fraud and embezzlement, this area should be considered as a high risk and need extra attention and monitoring from the regulating bodies, and during the internal and external audit.

\section{E. Disbursement Fund: Authorization}

Payment should be supported by relevant documents such as invoice and payment voucher and payment approval based on limits should be imposed to ensure good internal controls practices in cash disbursement and to avoid fraud [4]. All the 13 District Mosques used invoice and payment voucher as supporting documents for funds disbursement. The used of invoice by all District Mosques in making payment was considered as a good practice as it signified that no staffs were allowed to do advanced payments to suppliers and claimed for reimbursements at a later date. However, only seven District Mosques (53.85\%) imposed authorization based on limits. In practice, a good internal control should ensure that payment should have various level of authorization based on limits for which higher limit should involve a committee to make a decision for the payment to avoid fraud and embezzlement.

\section{F. Disbursement Fund: Segregation of Duties}

Reviewing the scores for segregation of duties, it can be concluded that majority of District Mosques (69.23\%) were able to segregate the custodial function and authorization function. However, low scores on SD1 and SD2 showed that majority of District Mosques did not practice a good segregation of duties in terms of recording and custodial functions.

\section{G. Disbursement Fund: Physical Custody}

All 13 District Mosques in the central region of Malaysia have a good control on cheque books which are kept in a safe place (e.g.: safe, locked box or locked drawer). 


\section{H. Comparisons of Internal Controls Practices between Authorization, Segregation of Duties and Physical Custody on Disbursement Funds}

Comparing the three average scores (A, SD, and PC) on internal controls for disbursing funds; it can be concluded that similar to findings on receipt of income, SD for disbursing funds was found to have the lowest score $(43.59 \%)$, and should be considered as having high risk of fraud. Further actions, attention and monitoring should be given by the regulating bodies. For example, training on proper accounting system should be organized by JAWI and JAIS to enhance internal controls practices by District Mosques in the central region.

\section{CONCLUSION}

The findings of this suggested that internal controls practices by District Mosques on both receipt of income and funds disbursement requires significant attention regarding the segregation of duties element. Other elements of internal controls such as physical custody, recording of transactions, and authorization were at the accepted level. This research contributed in improving the effectiveness and efficiency of District Mosques in central region of Malaysia by highlighting strengths and weaknesses in its internal control systems which could be used as guidance in enhancing the level of internal control implementation of religious organizations in Malaysia. Eliminating the weaknesses or problems identified may improve the control over the resources, strengthen accountability, improve financial reporting and improve relationship with the stakeholder, thereby enhancing their desire to continue supporting the religious organizations with financial. Highlighting strengths and weaknesses allow for a set of best practices to be collected and used to improve the internal accounting control system.

\section{REFERENCES}

[1] J. Hall, Accounting Information Systems, $6^{\text {th }}$ edition, USA: Cengage Learning, 2008.

[2] P. Palmer and A. Randall, Financial Management in the Voluntary Sector: New Challenges, London: Rutledge, 2002.

[3] M. Sulaiman, S. A. Siraj, and S. H. M. Ibrahim, "Internal Control Systems in West Malaysia's State Mosques," The American Journal of Islamic Social Sciences, vol. 25, no. 1, 2008.

[4] A. Cuomo. (August 2005). Internal controls and financial accountability for not-for-profit boards. [Online]. Available: www.oag.state.ny.us/charities/html

[5] W. A. Morehead, "Internal control and governance in non-governmental organizations designed to provide accountability and deter, prevent, and detect fraud and corruption," Ph.D. thesis, University of Southern Mississippi, 2007.

[6] Association of Certified Fraud Examiners (ACFE). (2004). ACFE fraud prevention check-up. [Online]. Available: http://www.acfe.com/fraud/check.asp

[7] The Committee of Sponsoring Organizations (COSO) of the Treadway Commission, Internal Control-Integrated Framework 4, New York: AICPA, 1992.

[8] P. Booth, "Accounting in churches: research framework and agenda," Accounting, Auditing \& Accountability Journal, vol. 6, no. 4, pp. 37-67, 1993.

[9] M. A. Adnan, "An investigation of the financial management practices of the Mosques in the Special Region of Yogyakarta Province, Indonesia," in Proc. Sharia Economics Conference, Hannover, February 9, 2013.
[10] J. B. Duncan and D. L. Flesher. "Does your church have appropriate internal control for cash receipts?" The National Public Accountant, pp. 15, Feb./Mar. 2002.

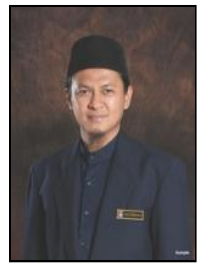

Mohamad Noorman Masrek is an associate professor at the Faculty of Information Management, Universiti Teknologi MARA (UiTM). He received his MSc in information management from UiTM and $\mathrm{PhD}$ in information technology from Islamic International University Malaysia (IIUM). His research interests are in the area of assessment of technology effectiveness; diffusion and infusion of technologies; systems design, development and implementation; strategic information systems planning; knowledge management and organizational behavior; data mining and knowledge discovery. He has published on various topics on his areas of expertise.

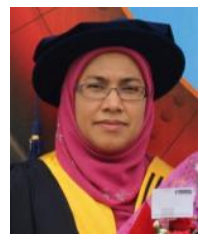

Intan Salwani is a senior lecturer at Faculty of Accountancy UiTM Shah Alam. As a research fellow at Accounting Research Institute (ARI), she actively involved in research activities such as representing UiTM and Malaysia in invention \& innovation competition in Geneva, Brussels, USA and South Korea and had won 34 medals at International and National levels. She had presented her research papers at IJAS Conference at Harvard University, USA (2010); EABR Conference in Prague, Czech Republic (2009); EABR Conference in Rothenburgh Germany (2008); and LSOM Conference at Korea University, Seoul (2007). Besides, her research articles were successfully published in Impact Factor Journals (ISI Thomson listed) such as Industrial Management and Data System (IMDS), Journal of Computer Informations System (JCIS), and Aslib Proceedings; and also SCOPUS listed journals such as Information Management and Computer Security (IMCS), International Journal of Services and Standards (IJSS), Maritime Policy and Management etc. Intan Salwani was awarded "Best Paper Award" at EABR Conference, Prague and "Promising Researcher Award" at CSSR conference, UiTM Malaysia.

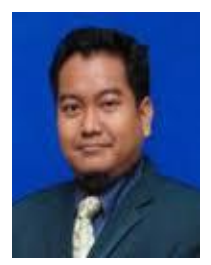

Norzaidi Mohd Daud is currently an associate professor of management (management information systems) in Faculty of Business Management, Universiti Teknologi MARA (UiTM), Malaysia as well as a visiting professor at King Saud University, Saudi Arabia. He received his doctorate degree in management specializing in human-technology interaction from Multimedia University (MMU), Malaysia under the Universiti Teknologi MARA Graduate Scholarship. He has published 7 books on management information systems, research methodology, innovation, portfolio management, waqaf management and over 80 articles on Management information systems, education management, economics, finance and management in SCOPUS, ISI Reuters journal outlets and conference proceedings.

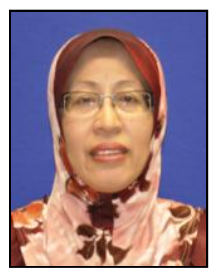

Roshayani Arshad is an associate professor at the Faculty of Accountancy, Universiti Teknologi MARA. She holds a PhD in accountancy from UiTM, master of accountancy from Glasgow University and is a graduate member of ACCA. She is currently the head of Financial Reporting Research Centre and research fellow at the Accounting Research Institute and actively involved in various research projects.

Her research interests include financial reporting, corporate disclosures, corporate social responsibility, reporting for non-profit organizations and corporate governance. She has also written several books on financial accounting and reporting.

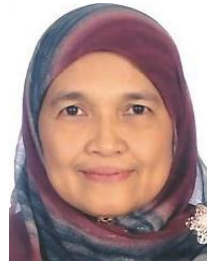

Normah Omar is currently the director of the Accounting Research Institute (ARI), Universiti Teknologi MARA. Her current research interest is in the area of forensic accounting and financial criminology. Recently ARI has been recognized as a national centre of excellence under the Ministry of Higher Education ( $\mathrm{HICoE})$.

Her current research interests are in the areas of: anti-money laundering \& Counter Financing of Terrorism (AML-CFT); fraud risk indicators; corporate integrity system; fraud prevention mechanism and islamic microfinancing. 